\title{
DIGI-INNO Tech: Reinventing Innovations
}

\author{
${ }^{1}$ Mrs Anchal, ${ }^{2}$ Mrs. Kanika Sharma \\ ${ }^{1,2}$ Asst. Prof in commerce, Hans raj Mahila Maha Vidyalaya, Jalandhar, India. \\ 1 anchalgrover96@gmail.com, ${ }^{2}$ kanikasharma187@gmail.com
}

\begin{abstract}
Digital-Innovation Technology calls for reinvention of innovations that offers new opportunities and challenges to design new products and services in the era of hi-tech competition. Digitalization and innovations are pressing issues for business in almost each and every industry. The scope to create new digital value chains increases at a very high speed due to interconnection of people and systems. It is to be believed that wonderful new ideas can open up new ways of looking at various Social Problems because of Digi-Inno connection between people and software. However creating digitalized product and services often creates new problems and challenges to the firm that are trying to innovate. The concept of reinvention in innovation process is redesigning the innovations coupled with advances in science and technology. Technological innovations are only one of many kinds of innovation that develops variety of terms like social innovation, sustainable innovation, responsible and green innovation. In this paper, we tried to give special emphasis on issues of digital innovation management which helps to seek a better base for reinventing innovation management research in digital innovative world.
\end{abstract}

Keywords: Digitizing, digitization, innovation, management

\section{INTRODUCTION}

Digital innovation is to be considering as the Innovative use of digital technologies which increases the competitiveness of our businesses and contributes to society's total productivity. It is the foundation of our future welfare as a nation digital technology. Digital innovation isn't about the technology itself, but rather about people's ability that how they utilize digital technology to solve their traditional problems. It is the process of leveraging advancements or innovating with technology to re imagine how business is done. It can also be used to explain, wholly or partially, the results of innovation and there are three traditional ways through which managers can guarantee that their innovation challenges are productive: foster different crowd roles to encourage contribution diversity; offer knowledge integration instructions and dual incentives; and offer explicit instructions for sharing different types of knowledge (Malhotra, A., and Majchrzak, A. 2014). In the reinvention scenario the nature and organization of products and services, creation of utilities, creation of demands, production and process of production, everything has changed rapidly, in a whole the transformation is made through innovations. The distinctive properties present in digital technology facilitates new scope of innovative course of action that are quick and complicated to control and forecast (Henfridsson, Mathiassen, \& Svahn, 2014; Yoo et al., 2012; Yoo, Lyytinen, Boland, \& Berente, 2010). Definition of digital innovation includes three important aspects i.e. A series of innovative results, that may include range of innovative products, platforms, and services this will also result into new customer-service experiences and other value pathways; if these results are innovative based on digital transformation, the results do not require to be digital but require a broad area of digi-tools and infrastructure for making innovation possible. The necessity for diffusion, assimilation, or adaptation to specific use of contexts with digital platforms.

\section{REVIEW OF LITERATURE}

Boudreau, K. 2010, in the paper named "Open Platform Strategies and Innovation: Granting Access Versus Devolving Control," distinguishes two fundamentally different approaches one defining new ways to start innovative techniques which provide access to initiate technology platforms and the other creating new markets for complementary components around the platform and to go further and give up control over the platform itself.

Bogers, M., and West, J. 2012, in the paper named "Managing Distributed Innovation: Strategic Utilization of Open and User Innovation," His study is based on the inference of the perception on the sources, incentive and value appropriation of external innovation, and provide an outline for the strategic management of distributed innovation and its origin $\&$ effects.

Malhotra, A., and Majchrzak, A. 2014, in the article named "Managing Crowds in Innovation Challenges", revealed the three ways to cater different crowd roles to encourage knowledge and offer explicit instructions. 
Nylén, D., and Holmström, J. 2015, In the article "Digital Innovation Strategy: AFramework for Diagnosing and Improving Digital Product and Services Innovation," revealed a framework and some implications of the framework in a rapid changing digital innovation environment.

Lyytinen, K., Yoo, Y., and Boland Jr., R. J. 2016, in the paper named "Digital Product Innovation Within Four Classes of Innovation Networks," focused on the emergence of four classes of innovation that follow the complete digital convergence and critically evaluate the nature and impact of innovation.

OECD. 2016, in the paper named "Stimulating Digital Innovation for Growth and Inclusiveness: The Role of Policies for the Successful Diffusion of ICT," provides information on different policies for the successful adoption and use of information and communication technologies (ICTs).

Nambisan, S. 2017, in the paper named "Digital Entrepreneurship: Toward a Digital Technology Perspective of Entrepreneurship," consider how digital technology build an existing entrepreneurship theories.

Rachinger, M.; Rauter, R.; Müller, C.; Vorraber, W.; Schirgi 2018, In the paper named "E Digitalization and its influence on business model innovation" revealed that representatives of the industries faces pressures along with opportunities of digitalization regarding BMI and provides the depth insights into the field of digitalization.

Kotarba, M.2018, In the article "Digital transformation of business models" explain the scope of changes in the various business models that took place in the recent years due to technological development known as digital transformation (DT)."

Guillermo, Fuertes.2020, In the article "Conceptual Framework for the Strategic Management: A Literature Review-Descriptive" presents the process of E-reading done with the help of using digital platform through number of investigations and scientific literature.

\section{What is Innovation?}

Innovation has never been so important and talked about as it is today. Everybody talks about innovation these days and innovation are present everywhere. But the question arises what is innovation?

"Innovation" comes from the Latin word "novus" which means new. From a financial point of view innovation is that which brings profit for a business and for the general public by introducing something new to it and Digital innovation means innovating goods, course of action, or business techniques using

Digi-tools as a means or end inside and crosswise organizations
Now what is Reinvention?

"Reinvention" is defined as "the extent to which an innovation is altered or tailored by a user in the process of its embracing and implementation" (Rogers, 2003)(p. 180). Reinvention, in simple words refers to as the changes made to a transformation that is different from basic intentions or plans.

Rice et al. (1980) suggested that reinvention can be categorized into three types:

- managerial reinvention which entails the theoretical approaches of the innovation;

- technical reinvention which entails conversion made to technical systems like mechanical systems; and

- Operational reinvention which deals with the changes in the working mechanism such as custom innovations, actions, and practices.

Particularly, such kind of renovation refers to as changes made to three elements:

- Innovation ideas that entails fundamental concepts and ideas on which innovations are based.

- Innovation objects are the material and physical components in the innovation.

- innovation practices are the implementation and use of the innovation by the adopters.

Thus, reinvention is re-creation of business, business ideology, business processes and procedures etc. It requires continue commitment: to invest sufficiently with the strategies closely aligned with the investment scale and digital leaders must be expose to high perils and must be willing to make/take daring decisions.

Digital Reinvention does not mean that whatever is manufactured is thrown away and completely new technology is used. Taking an example of Apple, when it moved from a computer manufacturer to music and lifestyle brand, it has reinvented itself while continuing to build computers. Similarly, this is the case with John Deere, brand name of Deere \& Company that manufactures agricultural, construction, forestry machinery, and others. It continued to sell tractors and farm equipment at the same time reinventing itself into a creator of online services for farmers.

Digital Reinvention is a new technological up gradation approach that focuses on improving future growth of business by using new digital techniques and tools.

\section{WHY REINVENTION}

Reinvention is not new to the market. The main difference is considered today is the fast growing market, interconnected global economy, hyper connected businesses and people enabled by the internet, which lead to reinvention of innovations .Many organizations have 
shifted their focus and started investing in multiple sources of innovations. Some of the factors that force reinventions are:

- 24/7 services: Due to connection of mobile devices and their contactable facility anytime, anywhere have the ability to perform all types of work. This forces businesses to adopt and adapt new technologies to reach more customers and grab market share.

- Technology driven companies/businesses: For growth, reinvention is necessary. Only those companies which are technology driven shows Exponential growth. In recent global innovation survey, it was seen that at least $50 \%$ of the top 20 most innovative companies were technology based companies, including Google, Twitter, Apple, Amazon and Netflix.

- Emergence of young entrepreneurs and startups: Big businesses are looking to acquire startups for their intellectual property, product/services etc. This permits the business to build innovation capability quickly.

- Customer demands the needs of customers are changing every time as the customer might be satisfied today with the product but might be demanding something else. Innovative business ideas actually have something strong to cater the changes in the market demand even at the time of rapid changing demands of customers.

- Smart and connected devices: Internet that connects everyone was estimated to be a US $\$ 3.8$ trillion industry in 2014. This digital transformation had played an important role in transforming the way we live, the way we work, the way we play and connect with each other. To match up with this ever-changing smart and connected devices reinvention is required.

- Future growth: Reinventions help in sustainable growth. A business that is ready to adopt innovation can stand confidently in constant ups and downs situations and able to face any challenges and pressure that market will bring to them

Thus, we can say that timing is everything, and you have to reinvent before you reach the top.

\section{Approaches to Digital Reinvention}

Digital Reinvention is need of an hour it can put you to new leadership board while increasing demand and creating new demands. Therefore, an organization must have a strategic approach to Digital Reinvention: The 5Ds of Digital Reinvention.
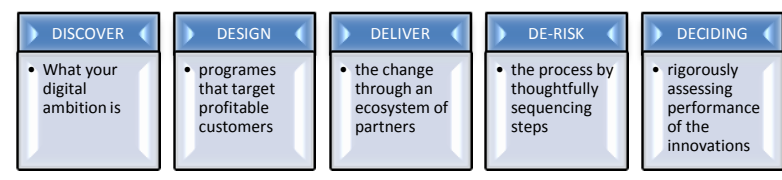

1. Discover. Discover means to develop a tight business case for change based on facts. Organizations must discover what your digital vision is based on where the value is. This will shape your digital ambition, strategy, and business case.

2. Design. To Design, to create, and prototype breakthrough experiences is the main focus of Design. It is reinventing and developing new capabilities and breakthrough

3. Deliver. This means where organizations need to gather speed and scale necessary for reinvention. Its primary focus is to deliver and develop a network of partners who can rapidly scale your goal.

4. De-risk. Focused on structuring the change program, resources, and commercial model to reduce operational and financial risk. It is necessary for senior leaders to focus on structural and organizational issues that can hamper the organization's ability to manage cyber risk.

5. Deciding. This D focuses on evaluation of the inventions to know whether the they are performing well or not and how much they are generating.

\section{Challenges due to ever changing Digi-tech innovations}

The main driver of change is technology which is headed by Digital Transformation. The basic challenges that drive economic growth are:

- Slow down Productivity \& Investment: Productivity is the main long-term Source of economic growth. Technology-enabled innovation is the major element to growth. Productivity growth has slowed as digital technologies have increased. Firms at the technological level have reaped major productivity gains, but the impact on productivity across firms has been considered weak. The new technologies leads to produce most outcomes and Dominant firms have acquired more market power, market structures have become less competitive and business dynamism has declined. Similarly Investment also has been weak in the major economies. Weak productivity growth and investment have reinforced the firms and are linked by similar shifts in market structures and dynamics.

- Shifts from unskilled labor to skilled labor market: labour market is affected by changing technology. Digital Innovation and reinvention are changing labor demand away from low- to middle-level skills to higher-level and managerial skills. On the supply side, 
however, slow learners who are unable to complement with the changing demads of skilled markets hinders the broader diffusion of innovations within the markets. This gap between demand and supply exists due to gap between learning and training methodology.this may lead to Unemployment.

- Rising Inequalities: A higher income inequality in different economies is the major reason of technological transformations. The capital intensive technologies and highly skilled technologies have reduced the income share of the lobor maket and raised the wage discrimination.it have been linked with structural industrial development and with firms taking high profit shares. This increases inequalities.

- Changing Growth Scenario: Due to rapid changing technologies many countries facing problem of Income inequality. As Technology poses many new challenges for the various countries for the economic growth, hence countries need some comparative advantages and need to develop alternatives ways to growth with rapid technology changes.

- Upcoming revolution of Artificial intelligence: technology is changing everyday this reshaping reinventing of technology is termed as artificial intelligence, advanced robotics, and cyber-physical systems taking the technological revolution to another level. The revolution in technology transformation is expected to be the "Fourth Industrial Revolution (4IR)." And the digital globalization is increasing day by day this digital globalization in context with 4IR will be termed as "Globalization 4.0."

So Innovation in digi-tech holds considerable effect to lift the growth of productivity and to create new and better jobs. The productivity growth in major economies in the coming years could be related to the new digital technologies. But these innovative changes will sometime considered as disruptive and leads to difficult transitions. And also creates winners and losers as globalization already does. Here good frameworks and policies play crucial role. Unfortunately, it seems to be slow to adapt these changes. So with the improved and more responsive and more better policies, better outcomes will be possible.

\section{Ways to overcome challenges:}

Businesses have been facing considerable challenges due to ever changing innovations. To overcome this, new business ideas, new minds and new start-ups is required. They can do this through adopting the various measures as suggested below:

\section{Bring reforms in learning and training systems}

- It is necessary to ensure digital skill oriented education system from kindergarten to higher schooling.So as to make kids aware of digital systems.

- Introduction of new educational tools is required for these online courses like MOOCs and SCOOPs are some good options.

- Promotion of long-run learning system is recommended,for e.g.online courses exhibiting digital training.

\section{Adopt a integrated skill oriented education}

- Education for digital Era: High skill oriented education is call for.Digi -tech education in synchronization with entrepreneurial competency is best learning approach. Inculcating involvement, creativity and learning critical thought process is mandatory in education system.

- More emphasis on know-how is prerequisite.Now, business houses/companies need to manage their skills rather than managing their jobs.

- Support co-operation between industry and other stakeholders to tailor vocational and academic training in ICT to labor market

- To ensure proper skill-oriented training private collaborators, stakeholders should give finance to businesses for various resources. Investment in skill training and learning is most important.

\section{Encourage budding entrepreneurs}

- Provide financial and other helping aids to nurture the budding entrepreneurs by initiating a Start-UP Process.

- Organize Young Entrepreneurs program globally: Toinspire budding Entrepreneurs EDPs (Entrepreneur Development Programs) should be organise worldwide. So that their mobility can be enhanced.

4. Support digitally innovative companies in their international growth

- $\square$ establish a real "innovation diplomacy" to simplify funding for projects and improve support for companies seeking to establish operations abroad.

- $\square$ Create a "one-stop-shop" to centralize information and procedures. 


\section{DEVELOP INNOVATION ECOSYSTEMS}

Encourage co-operation between large organizations \& newly started organizations as the innovative model of competitiveness

- Share best practices of market accessibility with startup facility enjoyed by large companies.

- Suggest a code of conduct that helps in building coordinating relations between big-shot companies and newly set up organizations and provide partnership deed arrangements.

- Facilitate the establishment of actual digi-tech innovative sites, so that stakeholders can advance to first place.

\section{CONCLUSION}

Digital technologic a Innovation programme needs proper management. This Digi -Tech innovation management is not only aimed managing the Internet services sector, but also wishing to generate new digital organizational opportunities. Digi-Tech management will constantly help the companies in managing the task and coordinating the activities to achieve a defined purpose and goals. As a result, Digi-tech innovation management will promote systematical innovations in organizations and includes the tasks of planning, organizing management and control. Innovative management deals with all measures to promote innovation in organizations and to generate benefits, for example: New to conquer new markets. Improved products and services to stand out from the competition Improve internal processes to strengthen the company from the inside or to save costs. Development to use new sources of income.

\section{REFERENCES}

[1] Bogers, M. \& West, J. 2012. Managing distributed innovation: Strategic utilization of open and user innovation. Creativity and Innovation Management, 21(1): 61-75. DOI: 10.1111/j.14678691.2011.00622.x (Pre-print version)

[2] Malhotra . A and Majchrzak .A, Managing Crowds in Innovation Challenges, California Management Review 56, no. 4 (summer 2014): 103-123.

[3] Nylén. D and Holmström .J. 2015, Digital innovation strategy: A framework for diagnosing and improving digital product and service innovation, Business Horizons, Volume 58, Issue 1, 2015, Pages 57-67, ISSN 0007-6813.

[4] Lyytinen, K., Yoo, Y., \& Boland Jr, R. J. 2016. Digital Product Innovation within Four Classes of Innovation Networks. Information Systems Journal, 26(1): 47-75.
[5] OECD (2016b), Stimulating digital innovation for growth and inclusiveness: The role of policies for the successful diffusion of ICT , OECD Digital Economy Papers, No. 256, OECD Publishing, Paris.

[6] Nambisan, S.2017: Digital entrepreneurship: toward a digital technology perspective of entrepreneurship. Entrep. Theory Pract. 41, 1029-1055 (2017)

[7] Rachinger, M.; Rauter, R.; Müller, C.; Vorraber, W.; Schirgi. 2018, E. Digitalization and its influence on business model innovation.J. Manuf. Technol. Manag. 2018.

[8] Kotarba, M. 2018. Digital transformation of business models. Foundations of Management, 10(1): 123142.

[9] Guillermo, Fuertes.2020, Conceptual Framework for the Strategic Management: A Literature ReviewDescriptive" in Journal of Engineering 2020(7):121 . January 2020.

[10] Boudreau, K. 2010. Open Platform Strategies and Innovation: Granting Access vs. Devolving Control. Management Science 56(10): 1849-1872. 